The risks of boar taint in fresh pork being very high in the Pietrain, castration should be maintained in this breed. As the optimal slaughter weight may be related to differences in the precocity of tissue development, the application of castration or not depends essentially on the possibilities of using male pig meat.

\title{
Influence of hypermuscularity and castration on the anatomical composition of ham in male pigs
}

\author{
B. L. DUMONT(1), T. BOULLEAU( ${ }^{(1)}$, J. LEF ÊBVRE( $\left.{ }^{2}\right)$ \\ (1) Laboratoire de Recherches sur la Viande \\ (2) Station de Génétique factorielle, \\ Centre national de Recherches zootechniques, I.N.R.A., \\ 78350 Jouy-en-Josas (France)
}

The influence of both the genetic type (hypermuscularity) and castration on the anatomical composition of the hind limbs of maie pigs was studied in Pietrain and Belgian Landrace breeds by considering I 7 Pietrain (I o entire males and 7 castrated) and 16 Belgian Landrace pigs (8 entire males and 8 castrated). Statistical analysis of results was entirely based on multivariate analysis; two types of analysis were performed, the analysis of centred data and the $\mathrm{D}^{2}$ of $\mathrm{Maha}$ lanobis.

Both types of analysis gave concordant informations and showed a significant effect of breed and sex.

As regards the overall tissue composition the castrated males were characterized by a higher covering fat percentage. Differences in muscle distribution were small and concerned mainly the anterior crural part.

Within each sexual type there were differences between breeds as for the muscle/bone ratio (higher in Pietrain and thus the most hypermuscled of both types) and the muscle distribution (smaller development of Rectus femoris and Gastrocnemius pars externa muscles, higher development of Adductor muscle in Pietrain).

In male pigs, the muscular hypertrophy did not affect in the same way the Pietrain and Belgian Landrace breeds each one showing different muscle distributions.

\section{Distribution of the Longissimus dorsi muscle in the dorso-lumbar area of the pig}

\author{
B. I. DUMONT \\ Laboratoive de Recherches sur la Viande, \\ Centre national de Recherches zootechniques, I.N.R.A., \\ 78350 Jouy-en-Josas (France)
}

The distribution of the mass of Longissimus dorsi muscle (LD) along the backbone was studied in pigs of normal (Large-White and Danish type) and hypertrophied conformation (Pietrain breed). In each conformation group animals with different numbers of thoracic and Lumbar vertebrae were considered, i.e. $20(N=6)$ and $2 \mathbf{I}(\mathrm{N}=7)$ vertebrae in hypertrophied animals and $2 \mathrm{I}(\mathrm{N}=9)$ and $22(\mathrm{~N}=\mathrm{IO})$ vertebrae in normal animals.

At the same carcass weight (half carcass of $35-36 \mathrm{~kg}$ ) there were highly significant differences in the average linear load of the backbone with LD muscle.

The load was higher in hypertrophied pigs $\left(35.5 \mathrm{~g}-\mathrm{cm}^{-1}\right)$ than in normal ones $\left(26.3 \mathrm{~g} . \mathrm{cm}^{-1}\right)$. 
Within each morphological type, the mass of LD muscle supported by each of the thoracic or lumbar vertebrae was highly variable along the backbone. When the number of vertebrae increased the distribution of its mass changed by a dilution phenomenon resulting from an increase in the length of the bone support of LD muscle.

When expressed in percentage of the total mass supported by each of the thoracic and lumbar vertebrae, the distribution of $L D$ muscle seemed to be the same in normal and in hypertrophied animals, in spite of the large reduction of backbone length in the latter.

\title{
Rearing houses for early weaned piglets: e ffect of climatic conditions and inside housing design on performances
}

\author{
J. LE DIVIDICH \\ Station de Recherches sur l'Élevage des Porcs, \\ Centre national de Recherches zootechniques, I.N.R.A., \\ 78350 Jouy-en-Josas (France)
}

This paper reports the most recent works about the housing of early weaned piglets (between 3 and 4 weeks of age) reared in groups on slatted floor. The effects of the bioclimatic environment parameters of the weaning house (temperature, relative humidity, velocity of the air) on the growth performance and the energy and nitrogen metabolism of piglets are analysed in the first part of the report. The effect of the weaning pen design (nature of the floor, surface per animal, number of piglets per pen) on growth and health are discussed in the second part.

The following main conclusions can be drawn from the results:

- The optimum temperature (dry bulb) for growth is high $\left(26\right.$ to $28^{\circ} \mathrm{C}$ ) during the first week after weaning corresponding to a period of low feed consumption in the piglet; it decreases, parallel to the temperature of thermal comfort, to $20^{\circ} \mathrm{C}$ at $8-9$ weeks of age. A bad regulation of the air temperature (variations of \pm 3 to $4^{\circ} \mathrm{C}$ around the average), especially during the first week after weaning, has a bad effect on the subsequent growth of the piglets and favours the appearance of diarrhoea, their frequency and persistence.

- The velocity of the air must be slow in the period of heating $\leqslant 10 \mathrm{~cm} \mathrm{~s}^{-1}$, corresponding to an hourly retiewal rate of 0.2 to $0.3 \mathrm{~m}^{3}$ per $\mathrm{kg}$ live weight. When, in the absence of heating, the temperature of the house is above the optimum for the piglet, an increase in the velocity of the air until $50-60 \mathrm{~cm} \mathrm{~s}^{-1}$ produces only a significant improvement of the piglet growth if the outside temperature is lower than the optimum temperature for the piglet.

- A relative humidity rate of $5^{\circ}$ to $7^{\circ} \mathrm{p}$. Ioo seems to be optimum.

-When the conditions of the thermal environment are met, the nature of the floor (concrete with straw, slatted floor or concrete) has little influence on the animals'growth.

However, the slatted floor improves the labor productivity and leads to a better utilization of the surface.

- The optimum surface per piglet between 5 and $25-30 \mathrm{~kg}$ live weight is $0.25 \mathrm{~m}^{2}$ according to the hypothesis of a discontinuous batch management of the herd (all-in all-out system). The number of piglets corresponding to an optimum utilization of the surface is 8-Io per pen. 